\title{
PRELIMINARY RESULTS OF SPECTROPHOTOMETRIC SCREENING OF SECONDARY METABOLITES ACCUMULATION IN LICHEN THALLOMS
}

(C) 2017

Gorina Maria Vladimirovna, postgraduate student of Ecology, Botany and Nature Protection Department

Kavelenova Lyudmila Mikhailovna, doctor of biological sciences, professor, head of Ecology, Botany and Nature Protection Department

Platonova Svetlana Alexandrovna, assistant of Chemistry Department

Samara National Research University (Samara, Russian Federation)

Abstract. This paper discusses the influence of biotopic conditions on the secondary compounds accumulation in lichen thalloms. Secondary metabolites inherent in the metabolism of various groups of organisms are widely represented in symbiotic organisms - lichens, with a significant number of these compounds being phenolic derivatives. The authors of the paper present the results of spectrophotometric scanning of alcohol extracts from lichen thalloms of three species: Xanthoria parietina (L.) Belt., Parmelia sulcata Tayl., Vulpicida pinastri (Scop.) J.-E. Mattsson \& M.J. Lai, sampled in different forest communities of the Krasnosamarsky forest (Samara Region), in 9 plots, where plant communities were fragments of natural forests (birch, aspen, linden, oak) and forest stands. Forest communities differed in their position in the relief, the composition of the arboreal stage, associated with the height and closeness of the plantations to microclimate conditions. The extracts obtained by infusion of $96 \%$ ethanol samples were analyzed using the AZURA UV / VIS UVD 2.1 L detector (190-750 nm, Knauer) in the laboratory of Chemistry Department of Samara University to obtain absorption spectra in the UV region using the ClarityChrom program. The study can be considered as an initial stage of bioecological screening, which makes it possible to ascertain the dependence of the secondary metabolites accumulation on habitat parameters in relation to the conditions of forest ecosystems in different parts of the Samara Region. The spectrophotometric study of the extracts demonstrated the presence of species-specific features of the spectra, indicating the differences in the qualitative composition of the extracts. For extracts obtained from samples of lichens were found spectra differences: quantitative - for all the species, and also qualitative - for Xanthoria parietina and Vulpicida pinastri extracts, related to qualitative and quantitative differences in the accumulation of secondary metabolites. These differences are presumably associated with differences in the biotopic conditions of growth of the thalli of the three studied lichen species.

Keywords: lichens; Samara Region; Xanthoria parietina (L.) Belt.; Parmelia sulcata Tayl.; Vulpicida pinastri (Scop.) J.-E. Mattsson \& M.J. Lai; alcohol extracts of thalli; spectrophotometric study; secondary metabolites accumulation; biotopical conditions influence; qualitative and quantitative differences of composition.

УДК 595.79

Статья поступила в редакцию 17.06.2017

\section{ОСОБЕННОСТИ ПАРАЗИТИЗМА НАЕЗДНИКОВ-ЭВЛОФИД (НYМЕNОРТЕRА: EULOPHIDAЕ) СРЕДНЕГО ПОВОЛЖЬЯ}

(C) 2017

Мищенко Андрей Владимирович, кандидат биологических наук, доцент кафедры географии и экологии Ульяновский государственный педагогический университет им. И.Н. Ульянова (2. Ульяновск, Российская Федерация)

Аннотащия. В данной статье приводится описание всех обнаруженных форм паразитизма наездниковэвлофид Среднего Поволжья, базирующееся на многолетнем опыте изучения биологии этой важной группы перепончатокрылых и значительном фактическом материале. Наездники-эвлофиды (Hymenoptera: Eulophidae) - семейство относительно мелких (не более 5 мм, обычно 1,5-2 мм) паразитических перепончатокрылых, личинки которых развиваются на фитофагах различных групп (прежде всего чешуекрылых, двукрылых, жесткокрылых). Многие виды растительноядных насекомых, подвергающихся заражению эвлофидами, являются вредителями лесного и сельского хозяйства, поскольку используют в качестве кормовых растения различных хозяйственно значимых семейств. Особую группу фитофагов составляют минёры, личинки которых развиваются скрыто в растительных тканях (например, мезофилле листа), образуя, часто видоспецифичные, повреждения - мины. Эвлофиды способны заражать минёров, находящихся внутри минирующих повреждений и недоступных другим видам энтомофагов, тем самым обеспечивая биологическую защиту культурным и дикорастущим растениям. При выполнении работы было проанализировано паразитическое развитие более 200 видов наездников данной группы, обнаруженных на территории исследований. В Среднем Поволжье выявлены представители всех 4-х подсемейств Eulophidae (Euderinae, Eulophinae, Entedoninae и Tetrastichinae), включающих более 40 родов [1-3]. Для указанных групп наездников приводятся особенности паразитического развития на хозяине, формы взаимодействия с другими видами эвлофид и внутривидовые отношения паразитирующих стадий.

Ключевые слова: эктопаразитизм; эндопаразитизм; грегарные паразиты; солитарные паразиты; эвлофиды; фитофаги; симблицид; гиперпаразитизм; мультипаразитизм; биологический контроль; минирующие насекомые; Euderinae; Eulophinae; Entedoninae; Tetrastichinae; Nepticulidae; Tischeriidae; Gelechiidae; Gracillariidae; Lyonetiidae; Yponomeutidae. 


\section{Актуальность исследований}

Изучение особенностей паразитизма хальцидоидных наездников семейства эвлофид (Hymenoptera: Eulophidae) является перспективным направлением энтомологических исследований, поскольку вносит вклад в познание экологии и биологии весьма важной группы перепончатокрылых, обеспечивающих естественный биологический контроль численности вредящих фитофагов. Для эвлофид характерно паразитирование на насекомых, преимагинальное развитие которых проходит скрыто внутри растительных тканей (минёры и галлообразователи из различных групп - чешуекрылые, двукрылые, перепончатокрылые, жесткокрылые и пр.), причем паразитизм осуществляется на личиночной стадии. В процессе взаимодействия с хозяином, особями своего вида и иными видами наездников возникают сложные отношения между указанными группами насекомых, что проявляется в различных приспособлениях и способах паразитизма (экто- и эндопаразитическое развитие эвлофид, явление гипер- и мультипаразитизма, а также симблицидное поведение личинок наездников).

\section{Материал и методы исследований}

Следует отметить, что изучение особенностей паразитизма эвлофид представляет определенные трудности, поскольку личинки данной группы наездников развиваются на фитофагах, ведущих скрытый образ жизни и питающихся внутри растительных тканей. Соответственно, для сбора материала от исследователя требуется хорошее знание флоры кормовых растений, на которых проходит преимагинальное развитие хозяев эвлофид, мест их произрастания, а также методик отбора поврежденных частей растения (мин, галлов и пр.) с живыми паразитами.

Материал собирался в ходе летних полевых выездов в Поволжье с 2016 по 2017 гг. Исследования осуществлялись во время вегетационного периода (май - август) в районе с $56^{\circ}$ по $52^{\circ}$ с.ш. и с $49^{\circ}$ по $44^{\circ}$ в.д. в пунктах с произрастающими растениями, служащими кормовой базой для минирующих насекомых из отрядов чешуекрылых, двукрылых, жесткокрылых, а также галлообразователей из группы пилильщиков. Вегетативные и генеративные части растений тщательно осматривались на наличие повреждений и проводился отбор материала с личинками и куколками фитофагов и развивающимися на них наездниками.

В лаборатории для дальнейшего изучения были созданы условия для сохранения жизнеспособности как самих хозяев, так и их паразитов. 97\% собранного материала составляли минирующие повреждения растений, локализующиеся в основном в мезофилле листа (пятновидные мины); также были собраны плоды, кора древесных и стебли травянистых растений со змеевидными ходами растительноядных насекомых и галлы (3\% собранного материала). Во избежание увядания собранные части кормовых растений сохранялись отдельно каждый в вентилируемых пластиковых контейнерах, в условиях периодического увлажнения при температуре $20-22^{\circ} \mathrm{C}$. Для исследования паразитизма наездников мины и галлы вскрывались и изучались при помощи стереоскопического микроскопа MC-2 ZOOM; фотографии были сделаны при увеличении $60^{\times}$камерой Samsung L73.
Имаго наездников-эвлофид определялись с использованием работ М. Грехема [4] и В.А. Тряпицына [5]. Идентификация фитофагов осуществлялась как по образуемым ими повреждениям на кормовых растениях [6;7], так и по морфологическим структурам имаго (генитальный аппарат, жилкование крыльев и пр.) [7-16].

Следует отметить, что цикл преимагинального развития минёров и галлообразователей может осуществляться или на кормовом растении, или же часть его проходит в почве (развитие куколок); причем для некоторых представителей после окукливания характерна длительная диапауза, и выход имаго происходит только после продолжительного периода с температурами ниже нуля. Части кормовых растений с развивающимися видами фитофагов, окукливание которых происходит в почве, помещались в контейнеры, содержащие небольшой слой земли (1,5-2 см). Если в развитии хозяев и наездников имела место зимняя диапауза, то собранный материал с полностью сформированными куколками помещался на 23 месяца в холодильник при температуре $0-4{ }^{\circ} \mathrm{C}$ для имитации холодного периода. Выходящие имаго фитофагов и наездников фиксировались эфиром и монтировались на тонкие минуции для составления коллекции и дальнейшей идентификации видов.

\section{Результаты исследований и их обсуждение}

Практически все изученные в Поволжье виды наездников-эвлофид являются полифагами, заражающими своих хозяев на одной из преимагинальных стадий развития. Характерной особенностью является паразитизм на скрытоживущих фитофагах, образующих внутри растительных тканей ходы различной формы (мины), а также галлы. В ходе проведенных исследований было выявлено, что в Поволжье эвлофиды являются паразитами минирующих чешуекрылых семейств Nepticulidae, Tischeriidae, Gelechiidae, Gracillariidae, Lyonetiidae и Yponomeutidae (Lepidoptera) (91\% всех выведенных эвлофид), мухагромизид (Diptera: Agromyzidae) (5\%), пилильщиков (Hymenoptera: Argidae, Tenthredinidae) (2\%), а также жесткокрылых (Coleoptera: Curculionidae) (2\%). Личинки указанных групп повреждают вегетативные (в основном листья), а также генеративные (плоды) органы более 50 видов цветковых растений в районе исследований, что нередко приводит к угнетению растений и дефолиации. Кроме того, следует отметить, что среди перечисленных отрядов насекомыхвредителей все чаще возникают вспышки численности и инвазии в соседние регионы, где данные виды ранее не встречались (например, на территории Поволжья в настоящее время продолжается инвазия липовой моли-пестрянки Phyllonorycter issikii, ильмового пилильщика Aproceros leucopoda и др.) [17; 18].

Заражению хозяина предшествует сложное поисковое поведение самок эвлофид (рис. 1), позволяющее безошибочно определять локализацию хозяина, скрывающегося в толще растительных тканей.

При помощи яйцеклада наездник осуществляет прокол в место расположения фитофага, после чего производится парализация насекомого и кладка либо на покровы хозяина (при эктопаразитизме), либо внутрь его тела (эндопаразитизм). Стратегию паразитизма большинства изученных в Поволжье видов 
эвлофид можно охарактеризовать как идиобионтную; при этом самки, парализуя и обездвиживая свою жертву, обеспечивают своё потомство пищевым ресурсом и укрытием внутри мины хозяина. Для эвлофид не выявлено тесное взаимодействие со своим хозяином в процессе паразитизма путем регуляции его развития выделением биологически активных веществ, замедляющих либо ускоряющих онтогенез, подавляющих иммунитет, регулирующих иные физиологические процессы хозяина (в случае паразитов с койнобионтной стратегией) [19]. Также не выявлено узкой трофической специализации данной группы наездников к определенным фитофагам; один и тот же вид эвлофид может паразитировать на представителях 2-3 отрядов насекомых из различных семейств. Критериями для выбора самками наездников объекта для яйцекладки являются: скрытое расположение личинки хозяина (что в дальнейшем обеспечивает также защиту потомства самого паразита внутри мин и галлов), размеры хозяина (должны обеспечить достаточный пищевой ресурс личинкам наездника, особенно при множественном развитии нескольких особей на одном хозяине при грегарном паразитизме), стадия развития хозяина (большинство видов эвлофид в районе исследований являются личиночными паразитами). Для нахождения личинок фитофагов в толще растительных тканей, самки эвлофид активно пользуются антеннами, а при обнаружении хозяина нередко используют своеобразное «зондирование» яйцекладом, пронизывая эпидерму листа, пока не будет обеспечено точное попадание и парализация жертвы. Интересной является способность самок оценивать пищевой ресурс своего хозяина: для видов с грегарным развитием количество отложенных яиц пропорционально размерам развивающейся личинки фитофага. Например, самки вида наездников из подсемейства Tetrastichinae, Minotetrastichus frontalis, при малых размерах личинок хозяина (1-3 возраста), откладывают не более 3 яиц на их покровы; если же личинка минёра находится на последней стадии развития, имея максимальные размеры после периода питания, количество отложенных яиц может достигать 7 [20]. Важным фактором выбора является и стадия развития хозяина, поскольку эвлофиды чаще всего заражают личинок фитофагов, имеющих слабохитинизированные покровы, позволяющие паразиту осуществлять прокол и питание за счет высасывания гемолимфы хозяина (рис. 2) (после завершения развития паразита от хозяина остаются лишь покровы); реже питание осуществляется на куколках растительноядных насекомых, находящихся на ранних стадиях развития с незавершенной хитинизацией.

По некоторым данным [21], в основном эктопаразитическое развитие характерно для представителей подсемейства Eulophinae, эндопаразитическое - для Entedoninae, оба типа паразитизма имеют место в группах Euderinae и Tetrastichinae. В ходе исследований эндопаразитизм также был выявлен у представителей подсемейства Eulophinae, указываемых как эктопаразиты. Например, виды рода Pnigalio способны развиваться не только наружно на гусеницах и куколках молей-пестрянок (Lepidoptera: Gracillariidae), но и внутри них (рис. 3) Интересными являются обнаруженные особенности внутривидового и межви- дового взаимодействия эвлофид в процессе паразитизма. В литературных источниках описываются факты сиблицидного поведения личинок грегарных эндопаразитов, развивающихся совместно внутри одного хозяина [22]. В Поволжье эндопаразитические виды эвлофид из семейства Entedoninae в основном развиваются как солитарные паразиты, что исключает симблицид личинок как таковой. Обычно самки откладывают под покровы хозяина только одно яйцо, и развивающийся паразит полностью использует пищевой ресурс хозяина при эндопаразитическом типе развития. Множественное развитие характерно только для некоторых видов эктопаразитических наездников из подсемейств Eulophinae и Tetrastichinae. При этом нами также не наблюдалось конкурентного поведения паразитов одного вида, развивающихся совместно на хозяине. Например, для вида наездников-тетрастихин Minotetrastichus frontalis характерна кладка 1-7 яиц на гусеницы либо куколки минирующих молей, при этом выходящие личинки, являющиеся потомством одной самки, не конкурируют между собой и равномерно используют питательные вещества хозяина. Как правило, избегать сиблицидного поведения удается за счет оценки размеров самого хозяина перед его парализацией; при этом самки откладывают тем меньшее число яиц, чем более ранней является стадия развития личинок фитофага (и соответственно, меньше его размеры).

Явление внутривидовой конкуренции между личинками разных возрастов эвлофид было изучено на уже указанном ранее виде Minotetrastichus frontalis. В условиях недостаточной кормовой базы, а также при перенаселенности, когда на хозяине уже развиваются представители данного вида наездников, самки проводят повторную кладку в мины с уже зараженными гусеницами и куколками фитофагов. Выходящие личинки первого возраста в таком случае начинают развитие как эктопаразиты на личинках старшего возраста Minotetrastichus frontalis, а в случае завершающегося развития наездников своего вида, относящихся к потомству другой самки, также и на куколках паразитов.

Следует также отметить наличие такого явления, как гиперпаразитизм, среди изученных видов эвлофид Поволжья. Весьма распространенным гиперпаразитом в районе исследований является эктопаразитический наездник Minotetrastichus frontalis, присутствующий в паразитокомплексах многих минирующих молей [1]. В случаях, когда внутри мины на хозяине уже развивается наездник иного вида эвлофид и пищевой ресурс хозяина использован, самки заражают личинок либо куколок первичного паразита, и личинки Minotetrastichus frontalis развиваются на нем уже как вторичные паразиты. Нами отмечен гиперпаразитизм указанного вида на личинках и куколках эвлофид родов Chrysocharis, Pnigalio и Sympiesis, заражающих в Поволжье минирующих молейпестрянок (Lepidoptera: Gracillariidae). Представители рода Chrysocharis также были отмечены как гиперпаразиты с внутренним типом развития на куколках наездников рода Pnigalio.

Факт гиперпаразитического развития эвлофид на видах своего семейства говорит о широкой трофической специализации наездников изучаемой группы и 
Мищенко А.В.

Особенности паразитизма наездников-эвлофид (Hymenoptera: Eulophidae)..

03.02.00 - общая биология

их способности приспосабливаться к хозяевам разных видов, развивающихся скрыто в тканях растения, в зависимости от обстоятельств: при наличии внутри мины или галла фитофага паразитирование осуществляется на нем, в случае отсутствия хозяина наездники переходят к гиперпаразитизму, развиваясь на первичных паразитах других видов эвлофид либо на представителях своего вида, являющихся потомством другой самки (заразившей хозяина ранее).

Также следует отметить выявленный факт мультипаразитизма для наездников-эвлофид в Поволжье.

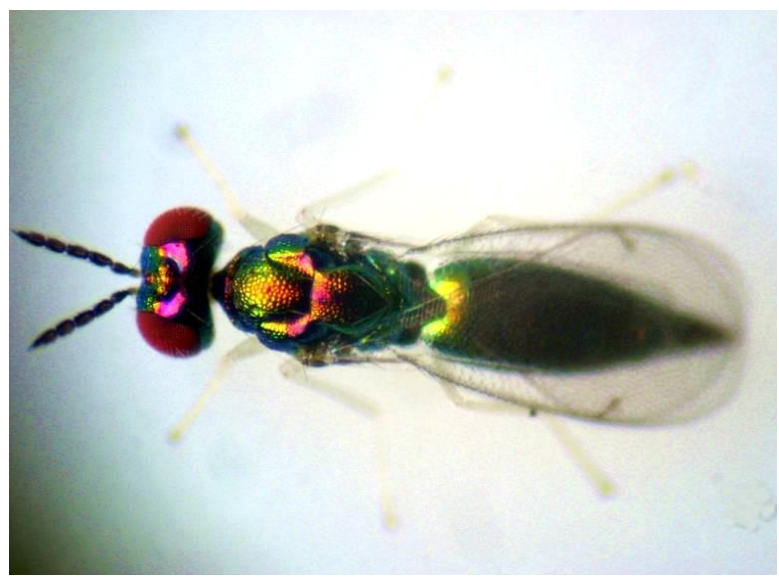

Рисунок 1 - Имаго наездника Chrysocharis sp.

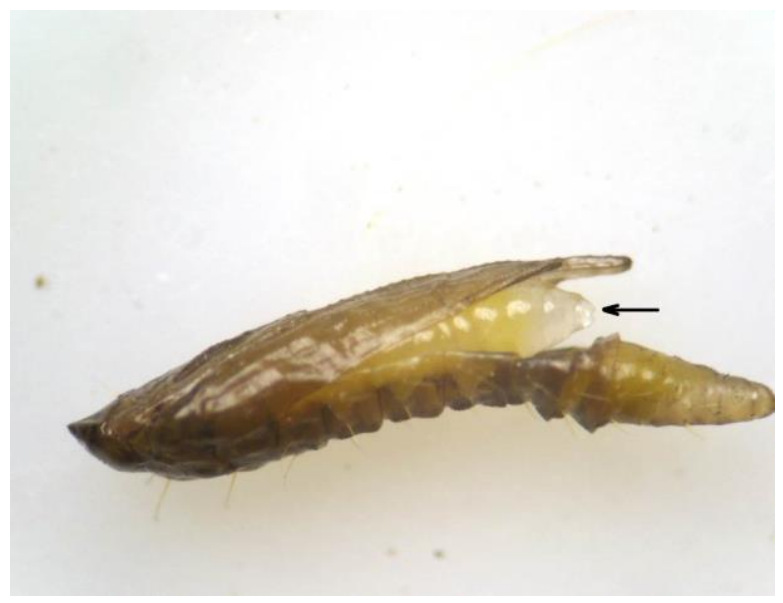

Рисунок 3 - Эндопаразитическое развитие наездника рода Pnigalio внутри куколки

минирующей моли-пестрянки Phyllonoryctersp.

Изученные в ходе исследований формы паразитического развития эвлофид позволяют сделать ряд важных выводов о стратегии наездников данного семейства. Паразитические перепончатокрылые Eulophidae являются группой с широкой пищевой специализацией (полифаги), приспособленные к развитию на скрытоживущих фитофагах (минёрах, галлообразователях и пр.). Эвлофиды являются наездниками с идиобионтной стратегией развития, приводящей к гибели хозяина при питании на нем личинок наездников; при этом самки паразитов обеспечивают свое потомство необходимым пищевым ресурсом, необратимо парализуя хозяина, развитие которого далее не происходит. Способность эвлофид развиваться не только на растительноядных насекомых, но и при от-
При изучении паразитизма перепончатокрылых этой группы на минирующих молях вида Phyllonorycter issikii, обнаружено совместное развитие личинок Minotetrastichus frontalis и Sympiesis gordius (рис. 4), наездников, преобладающих, например, в паразитокомплексе липовой моли-пестрянки [1; 17]. Следует отметить, что подобное явление редко встречается в семействе, поскольку между разными видами эвлофид при совместном развитии на хозяине выявлены многочисленные факты антагонизма.

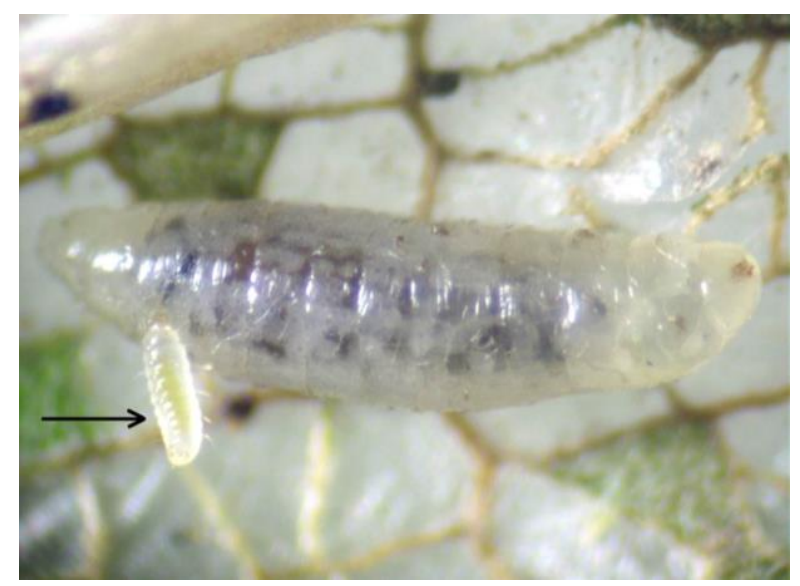

Рисунок 2 - Развитие личинки наездника Minotetrastichus frontalis (указана стрелкой) на хозяине

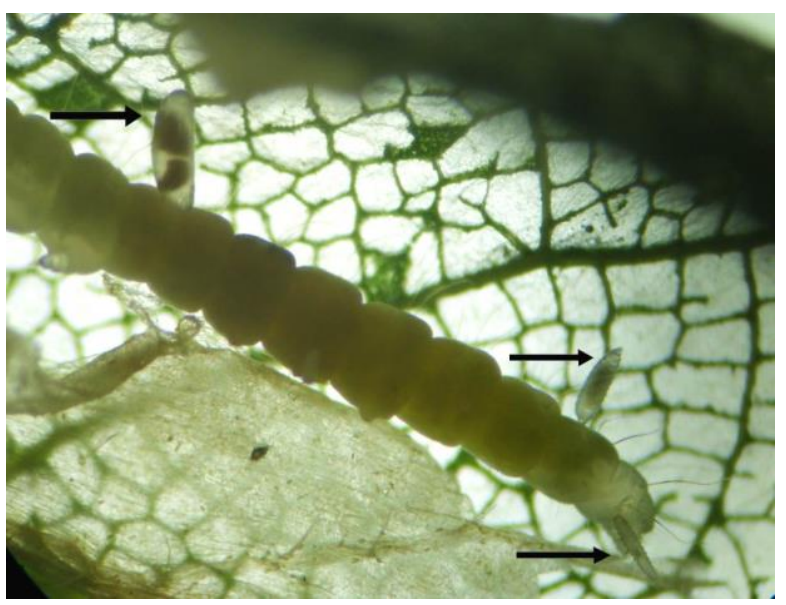

Рисунок 4 - Совместное развитие двух личинок наездника Minotetrastichus frontalis

(указаны стрелками в правой части фото)

и Sympiesis gordius (указан стрелкой в левом верхнем углу фото)

на гусенице липовой моли Phyllonorycter issikii

сутствии хозяина переходить к гиперпаразитизму говорит о высокой степени приспособляемости представителей семейства и экологической пластичности, что обеспечивает выживаемость видов при недостаточной кормовой базе фитофагов. Необходимо также отметить значение эвлофид как естественных регуляторов численности насекомых-вредителей, развивающихся в толще растительных тканей под их защитой. Способность наездников находить скрытоживущих фитофагов, прерывать их развитие и, соответственно, дальнейшее повреждение органов растения, делает указанную группу перепончатокрылых ценным объектом исследований в плане обеспечения биологической защиты выращиваемых человеком культурных растений. 


\section{СПИСОК ЛИТЕРАТУРЫ:}

1. Ефремова 3.А., Мищенко А.В. Новые данные о трофических наездников Eulophidae (Hymenoptera: Chalcidoidea) с чешуекрылыми (Lepidoptera) в Среднем Поволжье // Энтомологическое обозрение. 2009. T. 88, № 1. C. 29-37.

2. Ефремова 3.А., Мищенко А.В., Краюшкина А.В. Комплексы паразитоидов (Hymenoptera, Eulophidae) молей-пестрянок рода Phyllonorycter (Lepidoptera, Gracillariidae) в Среднем Поволжье // Зоологический журнал. 2009. Т. 88, № 10. С. 1213-1221.

3. Ефремова 3.А., Мищенко А.В., Егоренкова Е.Н., Страхова И.С., Ленгесова Н.А. Комплексы наездников семейства Eulophidae (Hymenoptera), паразитирующих на Phyllonorycter apparella и Phyllonorycter populifoliella (Lepidoptera, Gracillariidae) - вредителей осины и тополя в Ульяновской области // Зоологический журнал. 2011. Т. 90, № 4. С. 438-444.

4. Graham M.W.R. de V. Keys to the British genera and species of Elachertinae, Eulophinae, Entedontinae and Euderinae (Hymenoptera, Chalcidoidea) // Transactions of the Society for British Entomology. 1959. Vol. 13. P. 169-204.

5. Тряпицын В.А. Надсемейство Chalcidoidea // Определитель насекомых Европейской части СССР. Т. 3. Ч. 2. Л.: Наука, 1978. С. 28-538.

6. Гусев В.И. Определитель повреждений лесных, декоративных и плодовых деревьев и кустарников. М.: Лесная промышленность, 1984. 472 с.

7. Johansson R., Nielsen E.S., Nieukerker E.J., Gustafsson B. The Nepticulidae and Opostegidae (Lepidoptera) of North West Europe // Fauna Entomologica Scandinavica. 1990. Vol. 23. 452 p.

8. Арнольди Л.В., Заславский В.А., Тер-Минасян M.E. Сем. Curculionidae - Долгоносики // Определитель насекомых Европейской части СССР. Т. 2. Жесткокрылые и веерокрылые. М.; Л., 1965. С. 485621.

9. Гершензон 3.С. Сем. Yponomeutidae - горностаевые моли // Определитель насекомых Европейской части СССР. Т. 4. Ч. 2. Л.: Наука, 1981. С. 331347.

10. Желоховцев А.Н. Отряд Hymenoptera - перепончатокрылые. Подотряд Symphyta (Chalastogastra) - Сидячебрюхие // Определитель насекомых Европейской части СССР. Т. 3. Ч. 6. Л.: Наука, 1988. $268 \mathrm{c.}$

11. Загуляев А.К. Сем. Tischeriidae - одноцветные моли-минёры // Определитель насекомых Европейской части СССР. Т. 4. Ч. 1. Л.: Наука, 1981. С. 6671.

\section{PECULIARITIES OF PARASITISM OF HYMENOPTERA: EULOPHIDAE IN THE MIDDLE VOLGA REGION}

(C) 2017
12. Кузнецов В.И. Сем. Gracillariidae (Lithocolletinae) - моли-пестрянки // Определитель насекомых Европейской части СССР. Т. 4. Ч. 2. Л.: Наука, 1981. C. $149-311$.

13. Пискунов В.И. Сем. Gelechiidae - Выемчатокрылые моли // Определитель насекомых Европейской части СССР. Т. 4. Ч. 2. Л.: Наука,1981. С. 659748.

14. Родендорф Е.Б. Сем. Agromyzidae - Минирующие мушки // Определитель насекомых европейской части СССР. Т. 5. Ч. 2. Л.: Наука, 1970. С. $233-$ 303.

15. Сексяева С.В. Сем. Lyonetiidae - Крохоткимоли // Определитель насекомых Европейской части СССР. Т. 4. Ч. 2. Л.: Наука, 1981. С. 420-430.

16. Nieukerken E.J., Zolotuhin V.V., Mistchenko A.V. Nepticulidae from Volga and Ural Region // Nota lepidopterologica. 2004. № 27. P. 125-157.

17. Ефремова 3.А., Мищенко А.В. Комплекс наездников-паразитоидов (Hymenoptera, Eulophidae) липовой моли-пестрянки Phyllonorycter issikii (Lepidoptera, Gracillariidae) в Среднем Поволжье // Зоологический журнал. 2008. Т. 87, № 2. С. 189-196.

18. Ленгесова Н.А., Мищенко А.В. Биология, экология и молекулярно-генетическое исследование ильмового пилильщика Aproceros leucopoda (Takeuchi, 1939) (Hymenoptera: Argidae) - вредителя вяза в Среднем Поволжье // Кавказский энтомологический бюллетень. 2013. Т. 9, вып. 1. С. 163-167.

19. Сугоняев Е.С., Войнович Н.Д. Адаптации хальцидоидных наездников (Hymenoptera, Chalcidoidea) к паразитированию на ложнощитовках (Hemiptera, Sternorrhyncha, Coccidiae) в условиях различных широт. М.: Товарищество научных изданий КМК, 2006. $263 \mathrm{c}$.

20. Мищенко А.В. Особенности преимагинального развития наездника Minotetrastichus frontalis (Nees) (Hymenoptera, Eulophidae) // Энтомологическое обозрение. 2012. Т. 91, № 1. С. 58-62.

21. Noyes J.S. Universal Chalcidoidea Database. World Wide Web electronic publication [Электронный pe-cypc] // http://nhm.ac.uk/chalcidoids.

22. Gumovsky A. Parasitism of Entedon costalis (Hymenoptera: Eulophidae) in Glocianus punctiger (Coleoptera: Curculionidae): an example of intentional discovery of the parasitoid-host association // Zootaxa. 2008. Vol. 1964. P. 40-68.

Исследование выполнено при финансовой поддержке РФФИ в рамках научного проекта № 1644-730131 р_а «Разработка препарата для биологической защиты растений от минирующих насекомых на основе культуры наездников-эвлофид».

\section{Mishchenko Andrey Vladimirovich, candidate of biological sciences, associate professor of Geography and Ecology Department Ulyanovsk State Pedagogical University (Ulyanovsk, Russian Federation)}

\footnotetext{
Abstract. This paper describes all the detected forms of parasitism of eulophid wasps in the Middle Volga Region, based on many years of study of this important group of Hymenoptera and significant factual material. Hymenoptera: Eulophidae is a family of relatively small (no more than $5 \mathrm{~mm}$, usually 1,5-2 $\mathrm{mm}$ ) parasitic hymenoptera; its larvae develop on the phytophages of various groups (primarily lepidopterans, Diptera, coleoptera). Many species of herbivorous insects that are infected with eulofids are pests in forestry and agriculture, since they are used as fodder plants of various economically important families. A special group of phytophages are leafminers, larvae of
} 
which develop secretly in plant tissues (for example, leaf mesophyll), often forming species-specific damage mines. Eulophid wasps are able to infect leafminers that are inside leafmine and not accessible to other types of entomophages, thereby providing biological protection to cultural and wild plants. During the work parasitic development of more than 200 species of eulophid wasps was analyzed. Representatives of 4 subfamilies Eulophidae (Euderinae, Eulophinae, Entedoninae and Tetrastichinae), including more than 40 genera, have been identified in the Middle Volga Region.

Keywords: ectoparasitism; endoparasitism; gregarious parasites; solitary parasite; eulophid wasps; phytophagous; entomophagous; superparasitism; siblicide; multiparazitizm; biological control; leafminers; Euderinae; Eulophinae; Entedoninae; Tetrastichinae; Nepticulidae; Tischeriidae; Gelechiidae; Gracillariidae; Lyonetiidae; Yponomeutidae.

УДК 581.9

Статья поступила в редакцию 20.06.2017

\section{СТРУКТУРА И ДИНАМИКА ЧУЖЕРОДНОГО КОМПОНЕНТА ФЛОРЫ ЖЕЛЕЗНЫХ ДОРОГ В ЛЕСОСТЕПНОЙ ЗОНЕ СРЕДНЕГО ПОВОЛЖЬЯ}

\section{(C) 2017}

Никитин Николай Александрович, аспирант кафедры биологии, экологии и методики обучения

Самарский государственный сочиально-педагогический университет (2. Самара, Российская Федераџия)

Аннотация. Работа является результатом многолетних наблюдений за чужеродным компонентом флоры железных дорог Среднего Поволжья. Наблюдения проводились на территории нескольких субъектов, имеющих различные конфигурации железнодорожной сети и интенсивность ее эксплуатации. Приведенные данные характеризуют чужеродный компонент как двухуровневую динамичную систему, состоящую из ядра и флуктуирующего внешнего пояса. Ядро представлено американскими и евроазиатскими инвазионными видами, прочно вошедшими в состав естественных растительных сообществ и способных к длительному произрастанию на одном месте. Внешний флуктуирующий пояс состоит из натурализовавшихся и чужеродных видов, постоянно или эпизодически присутствующих в составе рудеральной растительности, способных изменять свою численность в зависимости от условий обитания и эксплуатации железных дорог. Структурно чужеродная флора сформирована под действием экстремальных условий обитания, что находит отражение в преобладании однолетних травянистых растений ксерофитного спектра, а также космополитных сорняков. Таксономическая структура показывает обеднение видового состава, низкие значения видовой наполняемости родов, однако при этом родовая наполняемость семейств показывает относительно высокие показатели. В целом, чужеродный компонент флоры характеризуется значительной устойчивостью к экстремальным условиям обитания, способен к длительному существованию на определенной территории, с тенденцией к расселению в сопредельные территории, характеризующиеся сходными условиями обитания.

Ключевые слова: чужеродные виды растений; инвазионные виды растений; натурализовавшиеся виды растений; виды-трансформеры; степень натурализации; флора железных дорог; урбанофлора; динамика флоры; Среднее Поволжье; железнодорожная сеть; таксономическая трансформация; видовое разнообразие.

\section{Введение}

Проблема изучения флоры нарушенных экотопов является весьма актуальной и рассматривается в работах многих ученых как в нашей стране, так и за рубежом [1-9]. Поскольку под воздействием антропогенного фактора происходит частичная или полная трансформация условий обитания, вслед за ней меняется и структура флоры, приобретая специфические черты, нехарактерные для местных флор [2; $3 ; 10]$.

Флора железных дорог, как частный пример флоры нарушенных экотопов, также является объектом пристального внимания исследователей [11-17].

Строительство и эксплуатация железнодорожного полотна требует отчуждения прилегающих земель для формирования полосы отвода. Как правило, она представляет собой полосу шириной до 50 метров в обе стороны от полотна. В ее пределах дорожные службы проводят периодические работы по ремонту и эксплуатационному содержанию, которое включает в себя уничтожение сезонной растительности (собственно путь), спил многолетней растительности (откосы насыпи, прилегающая территория), замена балластного слоя, очистка водоотводящих лотков, кюветов, дюкеров.
Железные дороги, как сложный комплекс местообитаний, являются активным коридором для проникновения и закрепления чужеродных видов растений на новых территориях. Изучение динамики чужеродного компонента флоры железных дорог позволит всецело понять процессы флорогенеза, имеющие место в пределах полосы отвода железнодорожных магистралей, позволит уточнить степень натурализации некоторых видов, прогнозировать возможные границы распространения чужеродных растений. Своевременное обнаружение на подъездных путях к крупным городам популяций карантинных сорняков, а также потенциально инвазионных видов, представляющих угрозу здоровью населения, позволит предотвратить их проникновение в мегаполисы.

\section{Материалы и методы}

Исследования проводились на протяжении 20102016 годов, ими были охвачены несколько участков пути Куйбышевской железной дороги в пределах Самарской, Оренбургской, Ульяновской областей. Ключевые участки были заложены на различных типах магистралей с различным режимом эксплуатации: активно эксплуатируемый участок пути в пределах городской черты (частный сектор) от станции 